\title{
Kadar Total Lipid Mikroalga Nannochloropsis oculata Hibberd, 1981 (Eustigmatophyceae : Eustigmataceae) Berdasarkan Perbedaan Salinitas dan Intensitas Cahaya
}

\author{
Dea Davita Putri Arihanda*, Suryono, Gunawan Widi Santosa \\ Departemen IImu Kelautan, Fakultas Perikanan dan IImu Kelautan, Universitas Diponegoro \\ JI. Prof.H.Soedarto S.H, Tembalang,Semarang, Jawa Tengah 50275 Indonesia \\ ${ }^{*}$ Corresponding author, e-mail : deadavitaa@gmail.com
}

\begin{abstract}
ABSTRAK : Nannochloropsis oculata merupakan alga yang memiliki kadar lipid tinggi dan mudah dibudidayakan karena hanya bantuan cahaya matahari, karbon dioksida dan air laut mampu berkembang biak dengan baik. Penelitian ini bertujuan untuk mengetahui pengaruh perbedaan salinitas dan intensitas cahaya terhadap pertumbuhan dan kadar total lipid pada mikroalga $N$. oculata. Penelitian ini dilaksanakan secara laboratoris, dengan Rancangan Faktorial. Perlakuan yang diuji cobakan yaitu A1( Salinitas $33 \%$ ), A2 (Salinitas $31 \%$ ), dan A3 (Salinitas $35 \%$ ), serta B1 (Intensitas Cahaya 500 lux), B2 (Intensitas Cahaya 1500 lux), B3 (Intensitas Cahaya 3000 lux), yang diperbandingkan dengan Perlakuan Kontrol. Setiap perlakuan dilakukan pengulangan sebanyak 3 kali. Hasil analisis pertumbuhan mikroalga $N$. oculata dan kandungan lipid dilakukan dengan Analisis Sidik Ragam dan dilakukan uji lanjutan Analisis Duncan Multiple Range Test dilaksanakan untuk mengetahui perbedaan perlakuan. Hasil penelitian menunjukkan bahwa pertumbuhan mikroalga $N$. oculata tertinggi dicapai oleh perlakuan A1B3 (Salinitas $33 \%$ dan Intensitas Cahaya 3000 lux) sebesar $19,927 \times 10^{3} \pm 5,454 \times 10^{3} \mathrm{sel} / \mathrm{mL}$ dan A3B1 (Salinitas $35 \%$ dan Intensitas Cahaya 500 lux) sebesar $20,779 \times 10^{3} \pm 5,874 \times 10^{3} \mathrm{sel} / \mathrm{mL}$. Pola pertumbuhan mikroalga $N$. oculata untuk semua perlakuan berbentuk kuadratik. Kandungan lipid mikroalga $N$. oculata tertinggi dicapai oleh perlakuan A3B1 (Salinitas $35 \%$ dan Intensitas Cahaya 500 lux) dengan nilai sebesar $66,5767 \pm 1,5257 \mathrm{mg} / \mathrm{g}$ dan terendah pada perlakuan A3B3 (Salinitas $35 \%$ dan Intensitas Cahaya 3000 lux) dengan nilai sebesar $38,2010 \pm 3,1507 \mathrm{mg} / \mathrm{g}$.
\end{abstract}

Kata Kunci : Nannochloropsis oculata, Lipid, Salinitas, Intensitas Cahaya

Total Lipid Contents of Microalgae Nannochloropsis oculata Hibberd, 1981 (Eustigmatophyceae: Eustigmataceae) Based on Differences in Salinity and Light Intensity

ABSTRACT : Nannochloropsis oculata is one of algae that has high lipid content compared to other algae and is easily cultivated because only the help of sunlight, carbon dioxide and sea water can reproduce well. This aims of the study was to determine the effect of varions salinity and light intensity on the growth and total lipid contents of microalgae N. oculata. The method used was an experimental laboratory method with a factorial design. The treatments applied were A1 (Salinity $33 \%$ ), A2 (Salinity $31 \%$ ), and A3 (Salinity $35 \%$ ), and B1 (Light Intensity 500 lux), B2 (Light Intensity 1500 lux), B3 (Light Intensity 3000 lux), which compare to the Control. The Interaction Treatments were applied on three replicates. The microalga $N$. oculata and Lipid Contents were analysed using Factorial Approach on Variance Analysis. The Duncan Multiple Range Test was applied to show the treatment which influence the difference result. The highest microalga $N$. oculata growth showed by the treatment of A1B3 (Salinity $33 \%$ and Light Intensity 3000 lux) with the number $19,927 \times 10^{3}$ cells $/ \mathrm{mL} \pm 5,454 \times 10^{3}$ cells $/ \mathrm{mL}$ and $\mathrm{A} 3 \mathrm{~B} 1$ (Salinity $35 \%$ and Light Intensity 500 lux) with the number $20,779 \times 10$ cells $/ \mathrm{mL} \pm 5,874 \times 10^{3}$ cells $/ \mathrm{mL}$. The growth model of $\mathrm{N}$. oculata for all treatments showed a model of quadratic. The highest lipid content of $N$. oculata showed by the treatment ofA3B1 (Salinity $35 \%$ and Light Intensity 500 lux) with the number $66,5767 \pm 1,5257 \mathrm{mg} / \mathrm{g}$ and the lowest on A3B3 (Salinity $35 \%$ and Light Intensity 3000 lux) with the number38,2010 $\pm 3,1507 \mathrm{mg} / \mathrm{g}$.

Keywords: Nannochloropsis oculata, Lipid, Salinity, Light Intensity 


\section{PENDAHULUAN}

Indonesia adalah negara kelautan yang mempunyai potensi sumberdaya alam sangat penting bagi kehidupan bangsa. Potensi tersebut perlu dikelola secara tepat agar dapat dimanfaatkan secara optimal dan lestari bagi kesejahteraan rakyat (Kusumaningrum \& Zainuri, 2013). Mikroalga merupakan makhluk hidup yang dapat tumbuh dan berkembang dilaut. Mikroalga termasuk kelompok tumbuhan berklorofil memiliki satu sel atau banyak sel dengan membentuk koloni. Alga memiliki kandungan bahan-bahan organik seperti polisakarida, hormon, vitamin, mineral dan juga senyawa bioaktif. Mikroalga dapat dimanfaatkan sebagai pakan alami, makanan dengan kandungan energi dan serat tinggi, bahan obat herbal, serta sebagai bahan bakar pengganti fosil, yang pada saat ini telah dikembangkan (Kusumaningrum dan Zainuri, 2013).

Lipid adalah nama suatu golongan senyawa organik yang meliputi sejumlah senyawa yang terdapat di alam yang semuanya dapat larut dalam pelarut-pelarut organik tetapi sukar larut atau tidak larut dalam air (Fessenden dan Fessenden, 1983). Lipid penting bagi manusia karena adanya asam-asam lemak esensial yang terkandung didalamnya. Fungsi lipid dapat melarutkan vitamin $\mathrm{A}, \mathrm{D}, \mathrm{E}$,dan $\mathrm{K}$ yang digunakan untuk memenuhi kebutuhan tubuh. Lipid merupakan sumber energi yang lebih efisien dibandingkan karbohidrat dan protein. Satu gram lipid/lemak dapat menghasilkan $9 \mathrm{Kkal}$, sedangkan karbohidrat dan protein hanya menghasilkan 4 Kkal setiap gram (Saifuddin, 2013).

Nannochloropsis oculata adalah salah satu mikroalga yang paling efisien dalam menangkap dan memanfaatkan energi cahaya dan $\mathrm{CO}_{2}$ untuk keperluan fotosintesis. Mikroalga ini bernilai tinggi dan memiliki kemampuan untuk berkembang biak hanya dengan menggunakan cahaya matahari, karbon dioksida dan air laut. Selain itu, N. oculata dapat tumbuh dengan kerapatan yang tinggi (50 dan $27.5 \mathrm{~g} / \mathrm{l}$ ) dalam kondisi tumbuh autothropic dan menghasilkan konten tinggi lipid (52\% dan 46\%) (Moazami et al., 2011).

\section{MATERI DAN METODE}

Materi yang digunakan dalam penelitian ini adalah mikroalga $N$. oculata yang diperoleh dari stok murni Laboratorium Balai Besar Pengembangan Budidaya Air Payau (BBPBAP) Jepara sebanyak 2 liter dengan kepadatan awal stok $171 \times 10^{6} \mathrm{sel} / \mathrm{mL}$. Penelitian ini menggunakan 9 box container dengan kapasitas 40 liter untuk setiap perlakuan. Masing masing perlakuan sebanyak $175 \mathrm{~mL}$ per box dengan air laut 30 liter. Parameter lingkungan yang diukur dalam penelitian ini ialah: DO, suhu, salinitas, intensitas cahaya, $\mathrm{pH}$, dan lipid. Perlakuan salinitas dalam penelitian ini menggunakan derajat konsentrasi $(A 1=33 \mathrm{ppt}),(\mathrm{A} 2=31 \mathrm{ppt})$ dan $(\mathrm{A} 3=35 \mathrm{ppt})$. Sedangkan perlakuan intensitas cahaya ialah (B1 = 500 lux $),(B 2=1500$ lux $)$, dan (B3 = 3000 lux $)$.

Metode penelitian yang dilakukan adalah metode eksperimental dimana menurut Sugiyono (2012) metode eksperimental merupakan metode penelitian yang digunakan untuk mencari pengaruh suatu perlakuan tertentu terhadap yang lain dalam kondisi yang dikendalikan. Data diperoleh selama penelitian dengan cara pengamatan dan pencatatan secara langsung.

Data pertumbuhan N. oculata diuji dengan Analisis Sidik Ragam dengan Pola Faktorial untuk membuktikan hipotesis yang telah disusun. Sedangkan pertumbuhan N. oculata berdasarkan waktu diuji secara deskriptif dengan menggunakan persamaan polinomial orthogonal untuk mengetahui hubungan diantara perlakuan dengan data ukur. Hasil Analisis Sidik Ragam selanjutnya diterapkan pada Analisis Uji Wilayah Ganda Duncan untuk mendapatkan perlakuan yang memberikaan perbedaan.

\section{HASIL DAN PEMBAHASAN}

Hasil analisis pola pertumbuhan $N$. oculata yang disebabkan oleh perlakuan yang berbeda disajikan Tabel 1 dan Gambar 1 menunjukkan bahwa seluruh perlakuan memberikan hasil pertumbuhan $N$. oculata dengan pola polynomial orthogonal. Nilai persamaan pertumbuhan $N$. oculata menunjukkan perlakuan yang berbeda dapat dilihat pada (Tabel 1). Hasil tersebut menunjukkan Signifikasi dikarenakan variasi pengaruh perlakuan guna mengetahui variasi antar perlakuan maka dilakukan uji sidik ragam (ANOVA) dapat dilihat Tabel 3. 
Tabel 1. Pertumbuhan mikroalga $N$. oculata rata - rata $\left(\right.$ sel $\left.\times 10^{3} / \mathrm{mL}\right)$ berdasarkan perlakuan kontrol, salinitas (A) dan intensitas cahaya (B).

\begin{tabular}{lrrrrrrrr}
\hline \multirow{2}{*}{ Perlakuan } & \multicolumn{7}{c}{ Pengamatan Hari Ke } \\
\cline { 2 - 9 } & \multicolumn{1}{c}{1} & \multicolumn{1}{c}{2} & \multicolumn{1}{c}{3} & \multicolumn{1}{c}{4} & 5 & 6 & 7 & 8 \\
\hline KONTROL & 10.750 & 11.950 & 32.800 & 31.000 & 50.600 & 55.116 & 40.716 & 29.216 \\
& & & & & & & & \\
A1B1 & 19.767 & 13.550 & 15.333 & 16.100 & 18.267 & 16.867 & 19.550 & 12.317 \\
A1B2 & 7.850 & 9.117 & 9.633 & 14.633 & 16.500 & 15.483 & 14.900 & 11.350 \\
A1B3 & 13.750 & 14.650 & 17.867 & 27.817 & 27.033 & 22.633 & 19.967 & 15.700 \\
RERATA & 13.789 & 12.439 & 14.278 & 19.517 & 20.600 & 18.328 & 18.139 & 13.122 \\
SD & 5.958 & 2.929 & 4.217 & 7.225 & 5.641 & 3.792 & 2.813 & 2.284 \\
& & & & & & & & \\
A2B1 & 19.433 & 15.883 & 16.250 & 13.550 & 16.033 & 15.867 & 19.600 & 12.505 \\
A2B2 & 8.417 & 11.700 & 12.467 & 16.867 & 16.750 & 19.683 & 15.983 & 11.250 \\
A2B3 & 15.017 & 17.000 & 14.533 & 13.567 & 16.467 & 17.867 & 12.292 & 10.100 \\
RERATA & 14.289 & 14.861 & 14.417 & 14.661 & 16.417 & 17.806 & 15.958 & 11.285 \\
SD & 5.544 & 2.794 & 1.894 & 1.910 & 361 & 1.909 & 3.654 & 1.203 \\
& & & & & & & & \\
A3B1 & 10.233 & 21.600 & 22.200 & 21.117 & 26.533 & 27.700 & 22.633 & 14.217 \\
A3B2 & 9.800 & 11.817 & 10.300 & 13.783 & 17.400 & 19.717 & 16.167 & 12.367 \\
A3B3 & 12.317 & 13.367 & 12.133 & 12.667 & 16.633 & 17.700 & 14.417 & 8.567 \\
RERATA & 10.783 & 15.594 & 14.878 & 15.856 & 20.189 & 21.706 & 17.739 & 11.717 \\
SD & 1.345 & 5.258 & 6.407 & 4.590 & 5.508 & 5.288 & 4.328 & 2.881 \\
\hline
\end{tabular}

Hasil kultivasi terhadap mikroalga $N$. oculata berdasarkan waktu pengamatan menunjukkan bahwa jumlah sel mikroalga (sel $\times 10^{3} / \mathrm{mL}$ ) rata rata mempunyai pola kuadratik, baik pada perlakuan kontrol maupun perlakuan penelitian salinitas $(A)$ dan intensitas cahaya (B). Jumlah sel mikroalga tertinggi dicapai pada perlakuan Kontrol sebesar $32,769 \times 10^{3} / \mathrm{mL}$, A1B3 sebesar $19,927 \times 10^{3} / \mathrm{mL}$ dan A3B1 sebesar $20,779 \times 10^{3} / \mathrm{mL}$ dimana lebih tinggi dari perlakuan A1B1, A1B2, A2B1, A2B2, A2B3, A3B2 dan A3B3. Hasil tersebut menunjukkan bahwa perlakuan kontrol dengan salinitas 32 ppt dan intensitas cahaya 1000 lux, perlakuan A1B3 dengan salinitas 33 ppt dan intensitas cahaya 3000 lux dan perlakuan A3B1 dengan salinitas 35 ppt dan intensitas cahaya 500 lux perlakuan yang lebih sesuai untuk menunjang pertumbuhan $N$. oculata. Hal ini ditunjang oleh pernyataan Cohen (2014) yang menunjukkan bahwa N.oculata hidup diair asin atau air laut dengan salinitas optimal yaitu 25-30 ppt namun memiliki toleransi pada salinitas 10-35 ppt. Hal lain ditunjang oleh pernyataan Cohen (2014) yang menyatakan bahwa $N$. oculata dapat hidup pada intensitas cahaya 100-10000 lux. Berdasarkan hasil tersebut perlakuan salinitas dan intensitas cahaya pada pertumbuhan N.oculata pada salinitas range 31-35 ppt dengan intensitas cahaya range 500-3000 lux mampu hidup dengan baik di wilayah tropis dan setiap harinya mengalami peningkatan dalam waktu 8 hari. Menurut Sen et al., (2005), Nannochloropsis sp dapat tumbuh optimum pada salinitas $25-35 \mathrm{psu}$, suhu $25-30^{\circ} \mathrm{C}, \mathrm{pH}$ 8-9,5 dan intensitas cahaya 100-10000 lux.

Perlakuan A1B3 dan A3B1 menunjukkan bahwa puncak pertumbuhan mikroalga $N$. oculata terjadi pada hari ke 5. Sedangkan perlakuan kontrol dan perlakuan yang lain menunjukkan bahwa puncak pertumbuhan mikroalga $N$. oculata terjadi pada hari ke 6 . Hasil tersebut menunjukkan pertumbuhan mikroalga $N$. oculata mengalami fase puncak atau fase akhir eksponensial. Hasil dari penelitian kandungan lipid tertinggi pada perlakuan A3B1 yaitu dengan salinitas $35 \mathrm{ppt}$ dan intensitas cahaya 500 lux menunjukkan bahwa puncak pertumbuhan mikroalga $N$. oculata terjadi pada hari ke 5. Sedangkan perlakuan kontrol dan perlakuan yang lain menunjukkan bahwa puncak pertumbuhan mikroalga $N$. oculata terjadi pada hari ke 6 . Pada fase ini kandungan nutrisi, $\mathrm{pH}$, salinitas, suhu dan intensitas cahaya pada medium kultur masih dapat memenuhi kebutuhan fisiologis sel ,sehingga Nannochloropsis sp. masih dapat tumbuh (Suantika, 2009). Menurut pernyataan Kawaroe et al. (2010) bahwa fase eksponensial merupakan tahapan pertumbuhan fase pertumbuhan lanjut yang dialami mikroalga setelah fase lag. Mikroalga yang dikultivasi akan mengalami pertambahan biomassa secara cepat. Hal ini ditunjukkan dengan penambahan jumlah sel yang sangat cepat melalui pembelahan sel mikroalga. Penambahan tersebut apabila dihitung 
secara matematis, maka akan membentuk fungsi logaritma. Untuk tujuan kultivasi sebaiknya mikroalga dipanen pada akhir fase eksponensial karena pada fase ini struktur sel masih berada pada kondisi normal dan secara nutrisi terjadi keseimbangan antara nutrien dalam media dan kandungan nutrisi dalam sel. Selain itu, umumnya pada fase akhir eksponensial, kandungan protein dalam sel sangat tinggi.

Hasil analisis menunjukkan bahwa perlakuan kontrol berbeda sangat nyata $(p<0,01)$ terhadap semua perlakuan yang lain. Selanjutnya diantara perlakuan A2B2, A2B3, A2B1, A1B1, A1B3 dan A3B1 menunjukkan hasil tidak berbeda nyata. Sedangkan perlakuan A2B2, A2B3, $A 2 B 1, A 1 B 1, A 1 B 3$ dan A3B1 menunjukkan perbedaan yang nyata $(p<0,05)$ terhadap perlakuan A3B2 dan A3B3 serta perbedaan yang sangat nyata $(p<0,01)$ terhadap perlakuan A1B2. Perlakuan A3B2 menunjukkan perbedaan yang nyata $(p<0,05)$ terhadap perlakuan A3B3 dan A1B2. Menurut Kawaroe et al. (2010), intesitas cahaya berperan penting dalam pertumbuhan N.oculata untuk melakukan fotosintesis, yaitu mengasimilasi karbon anorganik untuk dikonversi menjadi organik. Intensitas cahaya diperlukan tiap - tiap alga untuk dapat tumbuh secara maksimum yang berbeda - beda. Intensitas cahaya yang diperlukan bergantung pada volume dan densitas sel mikroalga. Hal ini mengakibatkan bahwa semakin tinggi densitas dan volume kultivasi semakin tinggi pula intensitas cahaya yang diperlukan. Menurut Kawaroe et al. (2010), salinitas air adalah salah satu faktor yang berpengaruh terhadap organisme air dalam mempertahankan tekanan osmotik yang baik antara protoplasma organisme dengan air sebagai lingkungan hidupnya. Mikroalga yang mengalami perubahan salinitas akibat pemindahan dari lingkungan bersalinitas rendah ke tinggi akan mendapat hambatan dalam proses fotosintesis. N.oculata hidup diair asin atau air laut dengan salinitas optimal yaitu 25-30 ppt namun memiliki toleransi pada salinitas 10-35 ppt (Cohen, 2014). Dalam penelitian ini perlakuan yang tepat untuk meningkatkan kepadatan sel terhadap pertumbuhan N.oculata yaitu salinitas range 31-35 ppt dengan intensitas cahaya range 500-3000 lux. Hasil analisis kurva pertumbuhan mikroalga $N$. oculata disajikan pada Gambar 1.

Hasil analisis terhadap pertumbuhan mikroalga $N$. oculata (Tabel 1) dalam bentuk persamaan berdasarkan perlakuan menunjukkan bahwa model pertumbuhan berbentuk eksponensial sebagaimana disajikan pada Tabel 2. Hasil uji sidik (ANOVA) Tabel 3 menunjukkan bahwa perbedaan perlakuan yang diujikan memberikan pengaruh sangat nyata $(P<0,01)$ terhadap pertumbuhan N. Oculata.

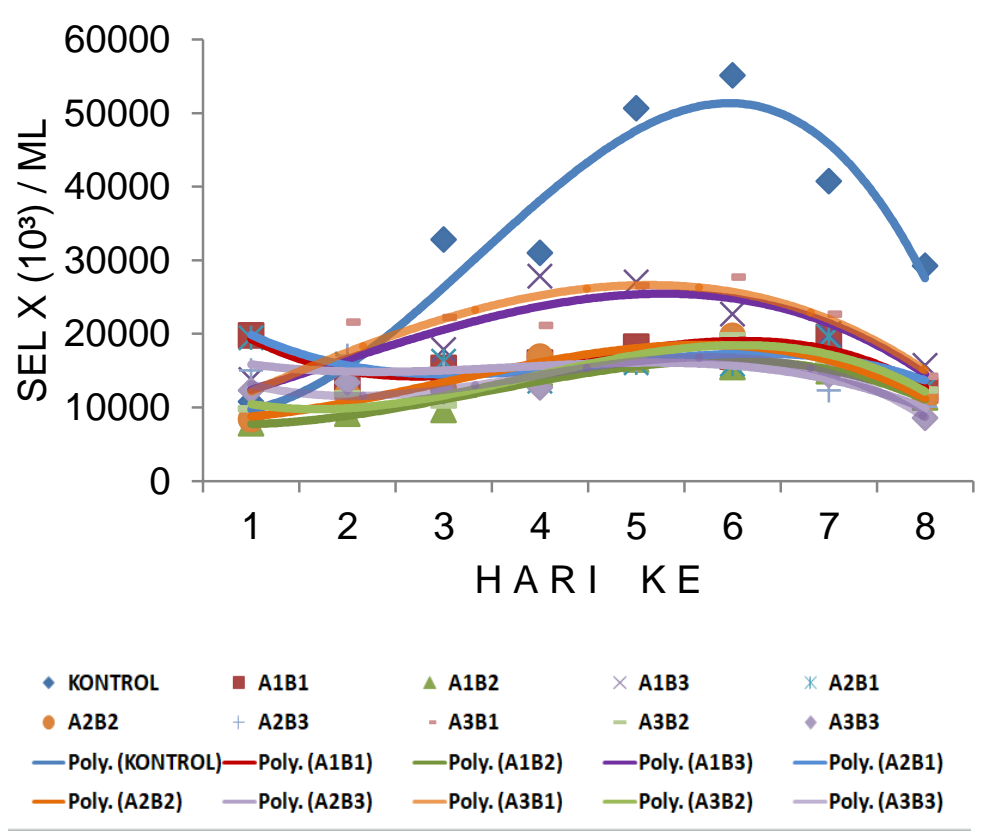

Gambar 1. Pertumbuhan mikroalga $N$. oculata $\left(\right.$ sel $\left.\times 10^{3} / \mathrm{ml}\right)$ berdasarkan berdasarkan perlakuan kontrol, salinitas $(A)$ dan intensitas cahaya $(B)$. 
Tabel 2. Persamaan pertumbuhan mikroalga $N$. oculata rata - rata (sel $\times 10^{3} / \mathrm{ml}$ ) berdasarkan perlakuan kontrol, salinitas (A) dan intensitas cahaya (B).

\begin{tabular}{cccc}
\hline No & Perlakuan & Persamaan & $R^{2}$ \\
\hline 1 & Kontrol & $y=-579,7 x^{3}+5806, x^{2}-7397, x+11903$ & 0,912 \\
2 & AlB1 & $y=-250,9 x^{3}+3324, x^{2}-12532 x+28756$ & 0,775 \\
3 & A1B2 & $y=-128,7 x^{3}+1305, x^{2}-1871, x+8420$ & 0,935 \\
4 & A1B3 & $y=-110,9 x^{3}+575,7 x^{2}+3226, x+8703$ & 0,804 \\
5 & A2B1 & $y=-181,4 x^{3}+2537, x^{2}-10476 x+27973$ & 0,599 \\
6 & A2B2 & $y=-130,6 x^{3}+1173, x^{2}-669,3 x+8389$ & 0,938 \\
7 & A2B3 & $y=-108,3 x^{3}+1211, x^{2}-3852, x+18610$ & 0,635 \\
8 & A3B1 & $y=-80,89 x^{3}+64,86 x^{2}+5733, x+6431$ & 0,824 \\
9 & A3B2 & $y=-203,4 x^{3}+2372, x^{2}-6258, x+14544$ & 0,895 \\
10 & A3B3 & $y=-208 x^{3}+2438, x^{2}-7392, x+18250$ & 0,858 \\
\hline
\end{tabular}

Tabel 3. Hasil Analisis Sidik Ragam Pertumbuhan mikroalga $N$. oculata (selx $\left.10^{3} / \mathrm{ml}\right)$ berdasarkan perlakuan salinitas (A) dan intensitas cahaya (B).

\begin{tabular}{lcccccc}
\hline \multicolumn{1}{c}{ SUMBER KERAGAMAN } & $\begin{array}{c}\text { DERAJAT } \\
\text { BEBAS }\end{array}$ & $\begin{array}{c}\text { JUMLAH } \\
\text { KUADRAT }\end{array}$ & $\begin{array}{c}\text { KUADRAT } \\
\text { TENGAH }\end{array}$ & $\begin{array}{c}\text { F HITUNG } \\
\text { F TABEL }\end{array}$ & 0,05 & 0,01 \\
\hline Variabel A (salinitas) & 2 & 419.994 .926 & 59.999 .275 & & & \\
Variabel B (Intensitas Cahaya) & 2 & 10.914 .428 .411 & 1.212 .714 .268 & $\begin{array}{r}33,1436 \\
* *\end{array}$ & 2,04 & 2,72 \\
$\begin{array}{l}\text { Interaksi salinitas dan intensitas } \\
\text { cahaya (A\& B) }\end{array}$ & 18 & 2.305 .148 .659 & 36.589 .661 & & & \\
\hline
\end{tabular}

**) Berbeda Sangat Nyata $(p<0,01)$

Berdasarkan hasil analisis sidik ragam untuk mengetahui perbedaan antar perlakuan, maka dilakukan uji lanjutan yaitu uji wilayah ganda Duncan. Uji tersebut dipilih untuk melakukan uji lanjutan.

Hasil lanjut uji wilayah ganda Duncan menunjukkan bahwa perlakuan kontrol berbeda sangat nyata $(p<0,01)$ terhadap semua perlakuan yang lain. Selanjutnya diantara perlakuan A2B2, A2B3, A2B1, A1B1, A1B3 dan A3B1 menunjukkan hasil tidak berbeda nyata. Sedangkan perlakuan A2B2, A2B3, A2B1, A1B1, A1B3 dan A3B1 menunjukkan perbedaan yang nyata $(p<0,05)$ terhadap perlakuan A3B2 dan A3B3 serta perbedaan yang sangat nyata $(p<0,01)$ terhadap perlakuan A1B2. Perlakuan A3B2 menunjukkan perbedaan nyata $(p<0,05)$ terhadap A3B3 dan A1B2. Hasil analisis tersebut menunjukkan jumlah sel mikroalga tertinggi dicapai pada perlakuan A1B3 (Salinitas 33 dan intesitas cahaya 3000 lux) dan A3B1 (Salinitas 35 dan intesitas cahaya 500 lux).

\section{Kandungan lipid mikroalga $N$. Oculata}

Hasil analisis kandungan lipid mikroalga $N$. oculata menunjukkan bahwa hasil tertinggi dicapai oleh perlakuan A3B1 dengan nilai sebesar 66,5767 $\pm 1,5257 \mathrm{mg} / \mathrm{l}$ dan terendah pada perlakuan A3B3 dengan nilai sebesar 38,2010 $\pm 3,1507 \mathrm{mg} / \mathrm{l}$ (Gambar 2). 
Tabel 4. Hasil Analisis Uji Wilayah Ganda Duncan terhadap Pertumbuhan mikroalga N. oculata (sel $\times 10^{3} / \mathrm{mL}$ ) berdasarkan perlakuan salinitas $(A)$ dan intensitas cahaya $(B)$.

\begin{tabular}{ccccccccccc}
\hline PRL & A1B2 & A3B3 & A3B2 & A2B2 & A2B3 & A2B1 & A1B1 & A1B3 & A3B1 & KONTROL \\
\hline NT & 12.433 & 13.475 & 13.919 & 14.140 & 14.605 & 16.410 & 16.469 & 19.927 & 20.779 & 32.769 \\
\hline & 20.336 & 19.294 & 18.850 & 18.629 & 18.164 & 16.359 & 16.300 & 12.842 & 11.990 & KONTROL \\
& 8.346 & 7.304 & 6.860 & 6.639 & 6.174 & 4.369 & 4.310 & 852 & A.3B1 & \\
& 7.494 & 6.452 & 6.008 & 5.787 & 5.322 & 3.517 & 3.458 & A1B3 & & \\
& 4.036 & 2.994 & 2.550 & 2.329 & 1.864 & 59 & A1B1 & & & \\
3.977 & 2.935 & 2.491 & 2.270 & 1.805 & A2B1 & & & & \\
& 2.172 & 1.130 & 686 & 465 & A2B3 & & & & & \\
1.707 & 665 & 221 & A2B2 & & & & & & \\
1.486 & 444 & A.3B2 & & & & & & & \\
1.042 & A.3B3 & & & & & & & & \\
\hline
\end{tabular}

PRL = Perlakuan ; NT = Nilai Tengah

Keterangan : Warna hijau menunjukkan berbeda sangat nyata $(P<0,01)$; Warna biru menujukkan berbeda nyata $(P<0,05)$

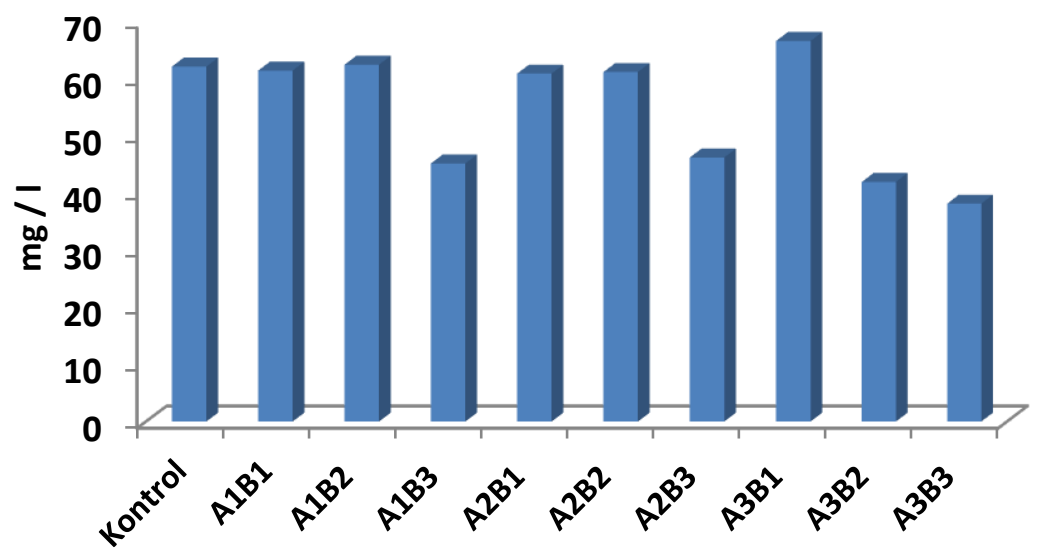

Gambar 2. Kandungan Lipid mikroalga $N$. oculata $(\mathrm{mg} / \mathrm{g})$ berdasarkan berdasarkan perlakuan kontrol, salinitas (A) dan intensitas cahaya (B).

Tabel 6. Hasil Analisis Sidik Ragam Kandungan Lipid mikroalga N. oculata berdasarkan perlakuan salinitas dan intensitas cahaya

\begin{tabular}{|c|c|c|c|c|c|c|}
\hline \multirow{2}{*}{ SUMBER KERAGAMAN } & \multirow{2}{*}{$\begin{array}{l}\text { DERAJAT } \\
\text { BEBAS }\end{array}$} & \multirow{2}{*}{ JK } & \multirow{2}{*}{$\begin{array}{l}\text { KUADRAT } \\
\text { TENGAH }\end{array}$} & \multirow{2}{*}{ F HITUNG } & \multicolumn{2}{|c|}{ F TABEL } \\
\hline & & & & & 0,05 & 0,01 \\
\hline Variabel A (salinitas) & 2 & 16,968 & 8,484 & & & \\
\hline Variabel B (Intensitas Cahaya) & 9 & 22.049 & 2.450 & $\left.525,8271^{* \star}\right)$ & 4,74 & 10,06 \\
\hline $\begin{array}{c}\text { Interaksi salinitas dan } \\
\text { intensitas cahaya (A\& B) }\end{array}$ & 18 & 83,864 & 4,659 & & & \\
\hline
\end{tabular}

**) Berbeda Sangat Nyata $(p<0,01)$ 
Hasil analisis sidik ragam kandungan lipid mikroalga $N$. oculata menunjukkan bahwa perlakuan yang diterapkan memberikan hasil yang berbeda sangat nyata $(p<0,01)$, dimana nilai $F$ hitung sebesar 525,8271 mempunyai nilai yang lebih besar dibandingkan dengan nilai $F$ tabel $(p<$ 0,01 ) sebesar 10,06. Berdasarkan hasil analisis sidik ragam pada Tabel 6, maka dilakukan analisis uji wilayah ganda Duncan (Tabel 7).

Hasil analisis menunjukkan bahwa perlakuan kontrol berbeda nyata $(p<0,01)$ terhadap semua perlakuan yang lain. Selanjutnya diantara perlakuan A3B3, A3B2, A1B3, A2B3 menunjukkan hasil berbeda sangat nyata. Sedangkan perlakuan A2B1, A2B2, A1B1, A1B2, A3B1 menunjukkan perbedaan yang nyata $(p<0,05)$. Hasil analisis kandungan lipid mikroalga $N$. oculata menunjukkan bahwa hasil tertinggi dicapai oleh perlakuan A3B1dengan nilai sebesar 66,5767 \pm $1,5257 \mathrm{mg} / \mathrm{L}$ dan terendah pada perlakuan A3B3 dengan nilai sebesar 38,2010 $\pm 3,1507 \mathrm{mg} / \mathrm{L}$.

Hasil analisis kandungan lipid mikroalga $N$. oculata menunjukkan bahwa hasil tertinggi dicapai oleh perlakuan A3B1dengan nilai sebesar 66,5767 $\pm 1,5257 \mathrm{mg} / \mathrm{g}$ dan terendah pada perlakuan A3B3 dengan nilai sebesar 38,2010 $\pm 3,1507 \mathrm{mg} / \mathrm{g}$. Hal ini menunjukkan bahwa perlakuan A3B1 memiliki nilai salinitas dan intensitas cahaya yang cukup optimal bagi pertumbuhan mikroalga $N$. oculata dibandingkan dengan perlakuan salinitas dan intensitas yang lain. Hasil penelitian pengaruh salinitas dan intesitas cahaya tertinggi pada perlakuan salinitas 35 ppt dan intensitas cahaya 500 lux. Hal ini ditunjang pernyataan oleh Andriyono (2001) bahwa mikroalga $N$. oculata membutuhkan cahaya untuk berfotosintesis. Apabila intensitas cahaya berkurang, maka akan menyebabkan proses fotosintesis tidak berlangsung normal sehingga mengganggu metabolisme selanjutnya dimana pembentukan lipid dipengaruhi oleh fotosintesis. Hasil fotosintesis berupa karbohidrat yang dipecah menjadi asam piruvat pada tahapan glikolisis, dimana asam piruvat akan disintesis menjadi asetil Co-a yang menghasilkan asam lemak dan gliserol. Asam lemak dan gliserol inilah sebagai penyusun lipid. Sedangkan pengaruh salinitas pada kandungan lipid menurut pertanyaan Kawaroe et al. (2010) merupakan faktor yang berpengaruh terhadap organisme air dalam mempertahankan tekanan osmotik yang baik antara protoplasma organisme dengan air sebagai lingkungan hidupnya dimana mikroalga mengalami perubahan salinitas akibat pemindahan dari lingkungan bersalinitas rendah ke tinggi terjadinya hambatan dalam proses fotosintesis. Dengan demikian jika salinitas terlalu tinggi akan menyebabkan terhambatnya pembentukan sel dimana akan memicu kematian pada mikroalga.

Tabel 7. Hasil Analisis Uji Wilayah Ganda Duncan terhadap Kandungan Lipid mikroalga $N$. oculata berdasarkan perlakuan salinitas dan intensitas cahaya.

\begin{tabular}{ccccccccccc}
\hline Perlakuan & A3b3 & A3b2 & A1b3 & A2b3 & A2b1 & A2b2 & A1b1 & A1b2 & $\begin{array}{c}\text { Kontro } \\
\text { I }\end{array}$ & A3b1 \\
\hline $\begin{array}{c}\text { Nilai } \\
\text { Tengah }\end{array}$ & 38,2010 & 41,9927 & 45,2030 & 46,2560 & 60,8893 & 61,1573 & 61,4223 & 61,5030 & 62,1040 & 66,5767 \\
\hline & 28,375 & 24,584 & 21,373 & 20,320 & 5,687 & 5,419 & 5,154 & 5,073 & 4,4727 & $\begin{array}{c}\text { Kontro } \\
\text { I }\end{array}$ \\
& 7 & 0 & 7 & 7 & 3 & 3 & 3 & 7 & & \\
& 23,903 & 20,111 & 16,901 & 15,848 & 1,214 & 0,946 & 0,681 & 0,601 & A1b2 & \\
& 0 & 3 & 0 & 0 & 7 & 7 & 7 & 0 & & \\
& 23,302 & 19,510 & 16,300 & 15,247 & 0,613 & 0,345 & 0,080 & A1b1 & & \\
& 0 & 3 & 0 & 0 & 7 & 7 & 7 & & & \\
& 23,221 & 19,429 & 16,219 & 15,166 & 0,533 & 0,265 & A2b2 & & & \\
& 3 & 7 & 3 & 3 & 0 & 0 & & & & \\
& 22,956 & 19,164 & 15,954 & 14,901 & 0,268 & A2b1 & & & & \\
& 3 & 7 & 3 & 3 & 0 & & & & & \\
& 22,688 & 18,896 & 15,686 & 14,633 & A2b3 & & & & & \\
& 3 & 7 & 3 & 3 & & & & & & \\
& 8,0550 & 4,2633 & 1,0530 & A1b3 & & & & & & \\
& 7,0020 & 3,2103 & A3b2 & & & & & & & \\
& 3,7917 & A3b3 & & & & & & & & \\
\end{tabular}

Keterangan : Warna hijau menunjukkan berbeda sangat nyata $(\mathrm{P}<0,01)$; Warna biru menujukkan berbeda nyata $(\mathrm{P}<0,05)$ 
Hasil dari penelitian kandungan lipid tertinggi pada perlakuan A3B1 yaitu dengan salinitas 35 ppt dan intensitas cahaya 500 lux menunjukkan bahwa pada salinitas dan intensitas tersebut mikroalga $N$. oculata mampu bertahan hidup dan memiliki kandungan lipid tinggi. Hal ini ditunjang oleh pernyataan Suantika (2009) bahwa pertumbuhan $N$. oculata sangat tergantung pada ketersediaan nutrien intensitas cahaya, suhu, karbondioksida, $\mathrm{pH}$ dan salinitas. Intensitas cahaya sangat diperlukan oleh mikroalga untuk menjalankan proses fotosintesis. Kurangnya intensitas cahaya yang dibutuhkan oleh mikroalga untuk aktivitas fotosintesis akan menyebabkan proses fotosintesis tidak berlangsung normal sehingga menggangu biosintesis sel selanjutnya.

\section{KESIMPULAN}

Berdasarkan dari hasil penelitian, maka diperoleh kesimpulan bahwa variasi salinitas dan intensitas cahaya berpengaruh terhadap pertumbuhan Nannochloropsis oculata, pertumbuhan mikroalga Nannochloropsis oculata tertinggi dicapai oleh perlakuan A1B3 ( Salinitas $33 \%$ dan Intensitas Cahaya 3000 lux ) sebesar $19,927 \times 10^{3} / \mathrm{mL} \pm 5,454 \times 10^{3} / \mathrm{mL}$ dan A3B1( Salinitas 35 $\%$ dan Intensitas Cahaya 500 lux ) sebesar $20,779 \times 10^{3} / \mathrm{mL} \pm 5,874 \times 10^{3} / \mathrm{mL}$, dengan pola pertumbuhan mikroalga Nannochloropsis oculata untuk semua perlakuan berbentuk kuadratik. Variasi salinitas dan intensitas cahaya berpengaruh terhadap kandungan lipid mikroalga Nannochloropsis oculata, hasil tertinggi dicapai oleh perlakuan A3B1 ( Salinitas $35 \%$ dan Intensitas Cahaya 500 lux ) dengan nilai sebesar 66,5767 $\pm 1,5257 \mathrm{mg} / \mathrm{g}$ dan terendah pada perlakuan A3B3 (Salinitas $35 \%$ dan Intensitas Cahaya 3000 lux ) dengan nilai sebesar 38,2010 \pm $3,1507 \mathrm{mg} / \mathrm{g}$.Berdasarkan hasil penelitian dan kesimpulan tersebut maka dapat disarankan untuk dapat dilaksanakannya penelitian lebih lanjut sehingga dapat melakukan analisis Omega-3, Omega-6, Omega-9 pada mikroalga $N$. oculata guna pemahaman yang lebih mendalam.

\section{DAFTAR PUSTAKA}

Andriyono, S. 2001. Pengaruh Periode Penyinaran Terhadap Pertumbuhan Isochrysis galbana Klon Tahiti. Makalah IImiah. IPB. Bogor. Hal 14-22.

Cohen, Z., 2014. Chemicals from microalgae. CRC Press.

Fessenden, R.J. \& Fessenden, J.S., 1983. Kimia organik. Penerbit Erlangga.

Kawaroe M., Prartono T., Sunuddin A., Wulan Sari D. \& Augustine D. 2010. Mikroalga Potensi dan Pemanfaatannya untuk Produksi Bio Bahan Bakar. Bogor:IPB Press. 108hal

Kusumaningrum H. P.\& Zainuri, M. 2013.Aplikasi Pakan Alami Kaya Karotenoid untuk Post Larvae Penaeus monodon Fab. IImu Kelautan: Indonesian Journal of Marine Sciences. 18:(3):143149

Moazami, N., Ranjbar, R., Ashori, A., Tangestani, M. \& Nejad, A.S., 2011. Biomass and lipid productivities of marine microalgae isolated from the Persian Gulf and the Qeshm Island. biomass and bioenergy, 35(5):1935-1939.

Saifuddin, S. 2013. Penuntun Praktikum Biokimia. Laboratorium Terpadu Kesehatan Masyarakat Regional Indonesia Timur. Universitas Hasanudin. Makassar. 135hal.

Sen, B., Alp, M.T. \& Kocer, M.A.T., 2005. Studies on growth of marine microalgae in batch cultures. I. Chlorella vulgaris (Chlorophyta). Asian Journal Plantad Science, 4(6):636-638.

Suantika, G. \& Hendrawati, D., 2009. Efektivitas teknik kultur menggunakan sistem kultur statis, semi-kontinyu, dan kontinyu terhadap produktivitas dan kualitas kultur Spirulina sp. Jurnal Matematika dan sains, 14(2):1-10.

Sugiyono. 2012. Metode Penelitian Kuantitatif Kualitatif dan R\&D. Bandung: Alfabeta.245hal. 